\title{
ANALISIS MINAT MASYARAKAT PERKOTAAN TERHADAP LAYANAN PRASARANA TRANSPORTASI DESA WISATA \\ Tiafahmi Angestiwi ${ }^{1}$, A. Gima Sugiama ${ }^{2}$ \\ Program Studi Manajemen Aset Politeknik Negeri Bandung \\ 1Email : tia.fahmi@polban.ac.id
}

\begin{abstract}
Transportation infrastructure is an important predictor of tourism. Tourism village as a form of tourism whose development is supported by surrounding transportation services. It is important to identify the service factors needed by tourists to tourist villages. This study aims to determine public perceptions of road infrastructure development from and to tourist villages and the criteria that need to be met by a tourist village. The research method used is applied research with a quantitative approach. Data collection techniques used to obtain primary data through questionnaires. The results of the study in the form of public perceptions of road infrastructure development from and to tourist villages have a negative impact on the environment, greatly impacting the benefits and living standards of local residents significantly. Meanwhile, the public perception of a tourist village needs to meet the criteria for the physical environment, amenities and accessibility.
\end{abstract}

Keywords: transportation infrastructure to and from tourist villages, criteria for tourist villages, accessibility of tourist villages

\begin{abstract}
ABSTRAK
Prasarana transportasi merupakan prediktor penting pada pariwisata. Desa wisata sebagai bentuk pariwisata yang perkembangannya didukung oleh layanan transportasi sekitar. Penting untuk didentifikasi faktor-faktor layanan yang dibutuhkan para wisatawan menuju desa wisata. Penelitian ini bertujuan untuk mengetahui persepsi publik terhadap pembangunan infrastruktur jalan dari dan menuju desa wisata serta kriteria yang perlu dipenuhi suatu desa wisata. Metode penelitian yang digunakan adalah penelitian terapan dengan pendekatan kuantitatif. Teknik pengumpulan data yang digunakan untuk mendapatkan data primer melalui kuesioner. Hasil penelitian berupa persepsi publik terhadap pembangunan infrastruktur jalan dari dan menuju desa wisata berdampak negatif terhadap lingkungan, sangat memberikan dampak manfaat dan standar hidup penduduk lokal secara signifikan. Sedangkan persepsi publik pada suatu desa wisata perlu memenuhi kriteria lingkungan fisik, amenitas dan aksesibilitas
\end{abstract}

Kata kunci: prasarana transportasi dari dan ke desa wisata, kriteria desa wisata, aksesibilitas desa wisata 


\section{PENDAHULUAN}

Pertumbuhan penduduk yang sangat cepat merupakan ciri umum perkotaan di Indonesia. Kebutuhan akan guna lahan berupa aktivitas ekonomi, sosial, dan budaya menjadi awal mula munculnya kebutuhan untuk melakukan perjalanan. Kebutuhan tersebut dapat dipenuhi dengan tersedianya sistem jaringan berupa prasarana transportasi. Prasarana merupakan kelengkapan dasar fisik suatu lingkungan, kawasan, kota atau wilayah. Prasarana adalah faktor potensial yang sangat penting menentukan arah perkembangan suatu wilayah. Oleh karena itu prasarana transportasi dapat mendorong berbagai potensi di kawasan perkotaan, salah satunya pariwisata.

Pariwisata adalah serangkaian aktivitas dan layanan yang disediakan baik untuk keperluan atraksi pariwisata, akomodasi, transportasi, dan layanan pendukung lainnya yang difungsikan untuk memenuhi keperluan dan kebutuhan perjalanan wisatawan untuk sementara meninggalkan tempat tinggalnya dengan maksud berbisnis, beristirahat ataupun maksud lainnya (Sugiama, 2013). Berdasarkan data statistik yang diperoleh dari BPS, kunjungan pariwisata oleh wisatawan asing selalu mengalami peningkatan dari tahun ke tahun. Namun dalam peringkat dunia, Indonesia masih tertinggal. Kondisi tersebut disebabkan kondisi infrastruktur yang belum memadai. Pariwisata yang ada saat ini kurang memperhatikan keberlanjutan yang mengakibatkan peningkatan biaya logistik. Hal tersebut berdampak pada investasi serta kelancaran perjalanan untuk pariwisata. Kondisi bandara, pelabuhan, jalan, dan hotel memperlihatkan kurang layaknya pengelolaan infrastruktur karena sejumlah besar wilayah di Indonesia dengan potensi pariwisata yang sulit untuk dijangkau. Perkembangan pariwisata suatu daerah bergantung pada perkembangan sistem transportasi (Sugiama, 2013).

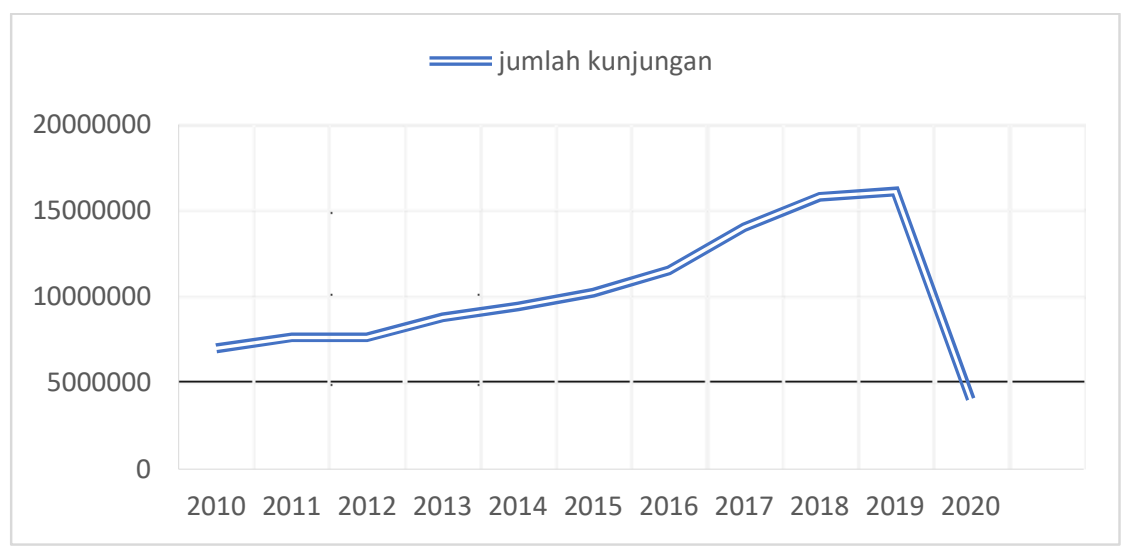

Gambar 1. Grafik Kunjungan Wisatawan Mancanegara ke Indonesia Sumber: BPS, 2020 
Menurut BPS, rata-rata wisatawan mancanegara datang dan tinggal selama sembilan hari untuk melakukan perjalanan wisatanya, bahkan cenderung menurun pada tahun 2019 (BPS, 2020) Tahun 2020 menurun drastis hingga rata-rata hanya dua hari tinggal menginap di hotel klasifikasi bintang. Kondisi masa pandemic membawa dampak yang sangat besar. Peningkatan pariwisata baik domestik maupun mancanegara merupakan upaya yang harus dilakukan untuk mengatasi perekonomian Indonesia (Virkar, 2018) Hal tersebut perlu menjadi prioritas bagi pemerintah, terutama di perkotaan sebagai fasilitator pembangunan prasarana. Proyek prioritas strategi nasional yang akan dibangun tahun 2021 sesuai dengan sasaran rencana pembangunan jangka menengah nasional (RPJMN) 2020-2024, yakni sektor industri, pariwisata, dan investasi di berbagai wilayah daerah (bisnis.com, 2020)

Akses transportasi dapat meningkatkan perkembangan wisata serta jumlah wisatawan karena akses menuju wilayah perkotaan menjadi semakin lancar (Soebriyantoro, 2009). Hal tersebut berdampak secara langsung terhadap ekonomi masyarakat sekitar, menciptakan lapangan kerja, meningkatkan pendapatan negara dan pemerataan pembangunan terutama mampu menggali potensi yang selama ini belum dikembangkan secara optimal. Adapun bentuk pembangunan prasarana transportasi darat berupa jalan dan jalan tol. Berikut kondisi kemantapan jalan daerah di Indonesia dapat dilihat pada Gambar 2.

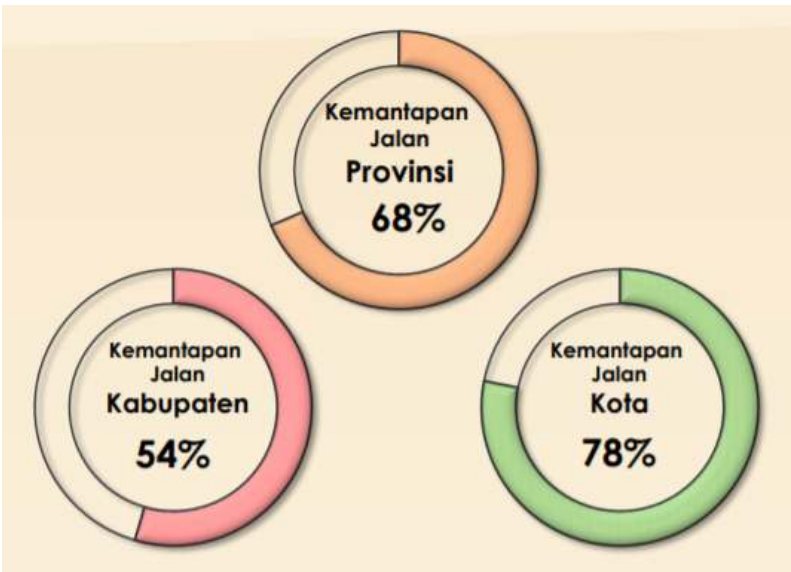

Gambar 2. Kondisi Kemantapan Jalan Daerah di Indonesia Sumber: Kementerian PUPR, 202

Secara umum kondisi kemantapan jalan di Indonesia dalam keadaan baik. Hal tersebut dapat mendorong tercapainya konektivitas antarwilayah. Sama halnya dengan pembangunan jalan tol yang sudah mencapai $2.100 \mathrm{~km}$. Dengan kondisi tersebut seharusnya 
dapat membantu mengembangkan potensi yang ada(pertanian dan perkebunan, perikanan, dan pariwisata) terutama kawasan pemukiman di perkota maupun pedesaan.

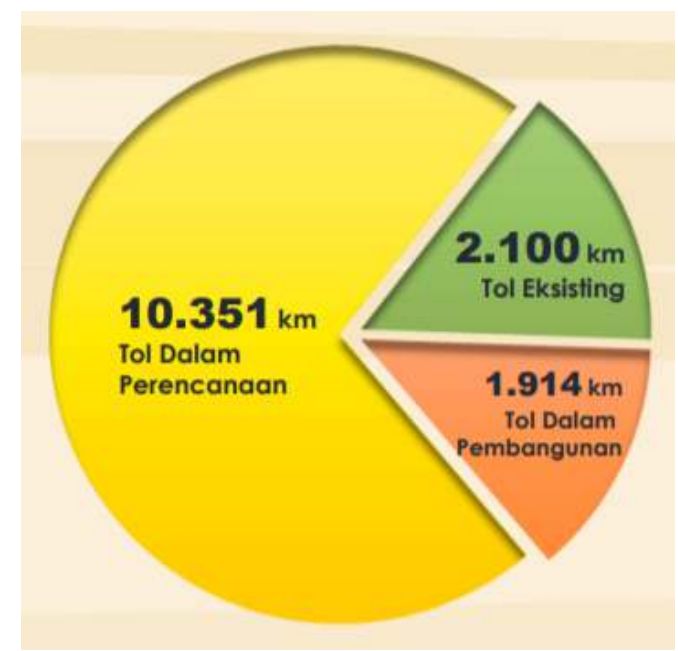

Gambar 3. Tol Dalam Pembangunan dan Rencana

Sumber: Kementerian Pekerjaan Umum dan Perumahan Rakyat, 2020

Berdasarkan BPS, tahun 2018 tercatat ada 1734 Desa Wisata dari 83.931 desa di Indonesia. Perkembangan daya dukung transportasi saat ini hanya mampu menampung 10,40 juta wisman. Hal tersebut memperlihatkan perlunya dukungan dari pemerintah setempat. Kapasitas pemerintah dalam memberikan pelayanan kepada masyarakat terutama masyarakat miskin melalui kebijakan pembangunan kepariwisataan yang terintegrasi (Kemenparekraf, 2010).

Berdasarkan Republika.co.id (Kamis, 27 April 2017) Model Desa Wisata yang menjadi prioritas pemerintah yakni keterlibatan masyarakat secara aktif dalam penyediaan akomodasi berupa homestay atau guesthouse, kebutuhan konsumsi wisatawan, pemandu, Transportasi lokal, pertunjukan hiburan, dan kesenian tradisional. "Model desa wisata yang ditetapkan Kementerian Pariwisata adalah desa wisata sebagai tujuan kunjungan tunggal atau single destination," kata Dadang di Denpasar, Kamis (27/4).

Data Bappenas menyebutkan jumlah desa wisata yang menjadi target dalam RPJMN 2020-2024 yaitu sebanyak 244 desa wisata dan 71.381 desa digital. Menurut Sekretaris Deputi Pengembangan Destinasi dan Infrastruktur Kementerian Pariwisata dan Ekonomi Kreatif Oneng Setya Harini, pemerintah akan mengkaji ulang profil desa wisata yang sudah ditetapkan sebelumnya. 
Dalam Keputusan Presiden RI No. 81 Tahun 2001 Tentang Komite Kebijakan Percepatan Pembangunan Infrastruktur, disebutkan dalam Pasal 2, bahwa pembangunan infrastruktur mencakup :

1. Prasarana dan sarana perhubungan: jalan, jembatan, jalan kereta api, dermaga, pelabuhan laut, pelabuhan udara, penyeberangan sungai dan danau;

2. Prasarana dan sarana pengairan: bendungan, jaringan pengairan, bangunan pengendalian banjir, pengamanan pantai, dan bangunan pembangkit listrik tenaga air;

3. Prasarana dan sarana permukiman, industri dan perdagangan: bangunan gedung, kawasan industri dan perdagangan, kawasan perumahan skala besar, reklamasi lahan, jaringan dan instalasi air bersih, jaringan dan pengolahan air limbah, pengelolaan sampah, dan sistem drainase;

4. Bangunan dan jaringan utilitas umum: gas, listrik, dan telekomunikasi.

Pemerintah sebagai fasilitator serta didukung potensi yang besar pada desa wisata di Indonesia, penting untuk dikaji lebih lanjut mengenai berbagai faktor penting yang harus diperhatikan dalam rangka peningkatan perekonomian khususnya masyarakat perkotaan.

Tujuan penelitian yang relevan untuk menyelesaikan permasalahan yakni untuk mengetahui minat masyarakat terhadap prasarana transportasi berupa:

1. Kondisi aksesibilitas dari dan menuju desa wisata berdasarkan persepsi publik yang pernah dan berpotensi mengunjungi desa wisata

2. Kualitas layanan prasarana transportasi dari dan menuju desa wisata berdasarkan persepsi publik yang pernah dan berpotensi mengunjungi desa wisata.

\section{KAJIAN TEORI}

\subsection{Transportasi}

Sistem transportasi menjadi 2 (dua) golongan yaitu transportasi makro dan transportasi mikro (Tamin, 2008). Sistem transportasi makro terdiri dari sistem kegiatan, sistem jaringan, serta sistem pergerakan, dapat dilihat pada gambar 1 (Sedayu, 2014). 


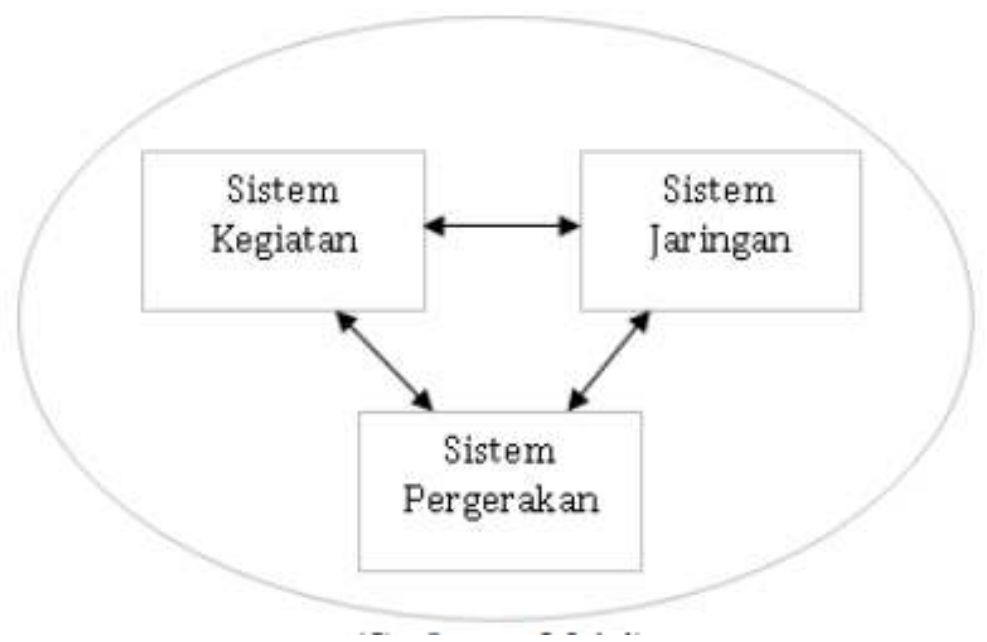

Gambar 4. Sistem Transportasi Makro

Sumber : Sedayu, 2014

1. Sistem Kegiatan, berkaitan dengan rencana mengenai tata guna lahan yang baik. Sistem merupakan awal mula terjadinya kebutuhan untuk melakukan perjalanan. Tamin mengemukakan bahwa ada tiga kegiatan penduduk yang meliputi kegiatan ekonomi, sosial, dan budaya (Tamin, 2008)

2. Sistem Jaringan, merupakan prasarana yang digunakan untuk memenuhi kebutuhan pada guna lahan tertentu. , terminal merupakan ruang lokal, kota regional, provinsi, pulau, maupun nasional. Sedangkan ruas disimbolkan dengan jalan, yaitu yang menghubungkan titik simpul asal (origin) dengan titik simpul tujuan (destination).

3. Sistem Pergerakan, merupakan hasil interaksi antara sistem kegiatan dengan sistem jaringan. Setiawan mengungkapkan bahwa interaksi kota merupakan gabungan dasar sebagai bentuk hubungan satu sama lain, keterkaitan sebagai bentuk reaksi menggabungkan pola dan kebiasaan individu pengguna lahan, kelompok, dan aktivitas terhadap kesatuan fungsi yang dideskripsikan sebagai subsistem (Setiawan, 2004). Pola perilaku tersebut akan membentuk suatu pertautan atau hubungan antara sub pusat 12 kegiatan.

\subsection{Desa Wisata}

Menurut Arida dan Punjami (2017), desa wisata merupakan salah satu bentuk penerapan pembangunan pariwista berbasis masyarakat dan berkelanjutan. Pendapat lain menurut Hermawan (2016), desa wisata adalah sebuah kawasan yang berkaitan dengan 
wilayah atau berbagai kearifan lokal (adat-istiadat, budaya, potensi) yang dikelola sebagai daya tarik wisata sesuai dengan kemampuannya, yang ditunjukan untuk kepentingan sosial dan ekonomi masyarakat. Menurut Zakaria dan Suprihardjo (2014:245), desa wisata adalah sebuah kawasan pedesaan yang memiliki beberapa karakteristik khusus untuk menjadi daerah tujuan wisata. Menurut Dewi et al. (2013:131), desa wisata merupakan salah satu bentuk penerapan pembangunan pariwisata berbasis masyarakat dan berkelanjutan. Melalui pengembangan desa wisata diharapkan terjadi pemerataan yang sesuai dengan konsep pembangunan pariwisata yang berkesinambungan. Di samping itu, keberadaan desa wisata menjadikan produk wisata lebih bernilai budaya pedesaan sehingga pengembangan desa wisata bernilai budaya tanpa merusaknya. Nuryanti dalam Dewi et al. (2013:131) menyebutkan, desa wisata merupakan suatu bentuk integrasi antara atraksi, akomodasi, dan fasilitas pendukung yang disajikan dalam suatu struktur kehidupan masyarakat yang menyatu dengan tata cara dan tradisi yang berlaku. Ditegaskan pula bahwa komponen terpenting dalam desa wisata, adalah (1) akomodasi, yakni sebagian dari tempat tinggal penduduk setempat dan atau/ unitunit yang berkembang sesuai dengan tempat tinggal penduduk, dan (2) atraksi, yakni seluruh kehidupan keseharian penduduk setempat beserta latar fisik lokasi desa yang memungkinkan berintegrasinya wisatawan sebagai partisipan aktif, seperti kursus tari, bahasa, lukis, dan hal-hal lain yang spesifik.

Terkait dengan konsep pengembangan desa wisata, Pearce (1995) mengartikan pengembangan desa wisata sebagai suatu proses yang menekankan cara untuk mengembangkan atau memajukan desa wisata. Secara lebih spesifik, pengembangan desa wisata diartikan sebagai usaha-usaha untuk melengkapi dan meningkatkan fasilitas wisata untuk memenuhi kebutuhan wisatawan. Menurut Sugiarti dalam Arida dan Punjami (2017:3), desa wisata, sebagai salah satu bentuk dari pariwisata pedesaan dapat memberikan banyak manfaat kepada upaya pengembangan berbagai sumber daya yang dimiliki oleh daerah pedesaan. Arida dan Punjami (2017:3) pun menyebutkan, pengembangan desa wisata disinyalir dapat mengatasi urbanisasi dan mendorong perekonomian pedesaan. Di samping itu pariwisata pedesaan berperan dalam meningkatkan kualitas hidup masyarakat pedesaan.

Rahman dalam Arida dan Punjami (2017:3) berpendapat, program pengembangan desa wisata tidak saja bertujuan untuk mendorong masyarakat desa dalam mengelola potensi alam serta budayanya secara kreatif sehingga menghasilkan manfaat ekonomi, namun lebih daripada itu ia juga bertujuan untuk menyiapkan masyarakat dalam menghadapi persaingan 
global. Pengembangan desa wisata memiliki tujuan utama untuk membangun masyarakat desa agar memiliki ketahanan budaya dan ekonomi. Dengan dukungan ekonomi atau modal yang memadai, masyarakat desa akan dapat mempertahankan dan mengembangkan warisan budayanya. Dengan demikian dalam pengembangan desa wisata yang berkarakter 'prorakyat' tujuan dan targetnya adalah memberikan kesempatan atau mendorong masyarakat agar lebih aktif, kreatif, dan pro-aktif dalam mengembangkan dan mengelola daya tarik wisata di daerahnya.

\subsection{Road And Transport Infrastructure And Community For Tourism}

Menurut Kanwal et al. (2020:2), akses ke lokasi pariwisata melalui jalan dan infrastruktur transportasi lainnya merupakan bagian penting dari pengembangan pariwisata. Sebuah lokasi pariwisata tidak bisa dinikmati jika sulit dijangkau karena tidak mencukupi jalan dan prasarana transportasi lainnya. Kanwal et al. (2019) menyebutkan bahwa perbaikan infrastruktur jalan dan transportasi dapat mengurangi waktu dan biaya terkait dengan perjalanan. Penelitian sebelumnya menemukan bahwa moda transportasi seperti jalan raya, kereta api, dan udara memiliki dampak positif terhadap kegiatan pariwisata (Kurihara \& Wu, 2016; Li et al., 2019; Masson \& Petiot, 2009).

Menurut Kanwal et al. (2020:3), jika lokasi wisata yang disukai ditandai dengan infrastruktur jalan dan transportasi yang buruk, harga yang mahal, dan perjalanan yang tidak nyaman, maka mereka yang ingin berkunjung pun akan mencari destinasi wisata alternatif. Oleh karena itu, jalan dan transportasi yang lebih baik disarankan sebagai prediktor penting dari kegiatan pariwisata (Khadaro \& Seetanah, 2007).

Menurut Kanwal et al. (2020:3), jalan dan transportasi merupakan faktor potensial dalam pengembangan pariwisata. Berikut adalah model konseptual tentang pentingnya jalan dan transportasi untuk perluasan industri pariwisata: 


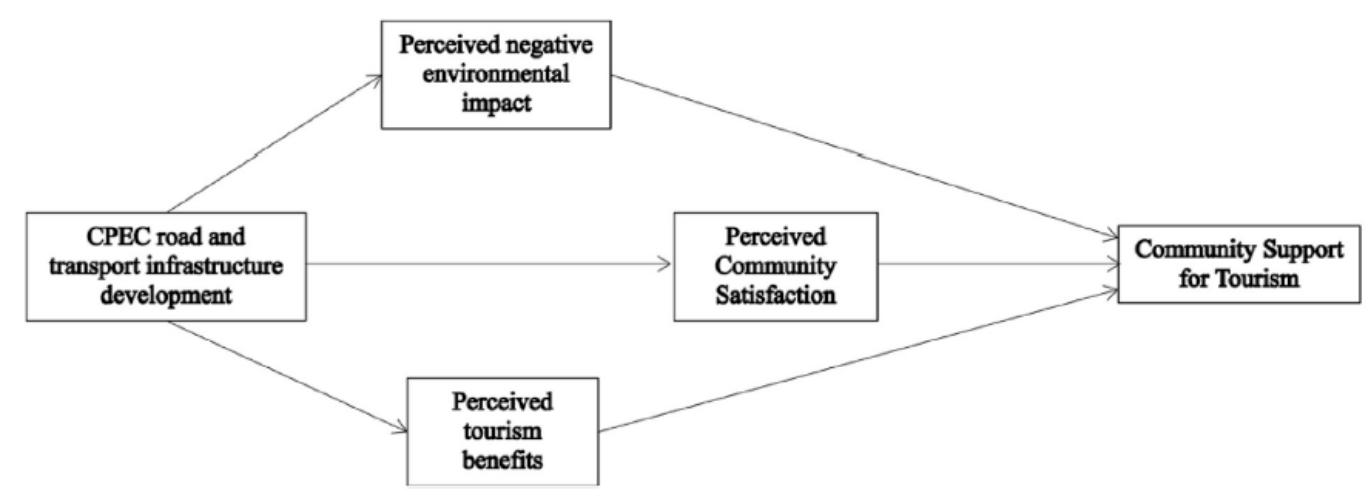

Gambar 5. Model Konseptual

Sumber: Kanwal et al. (2020)

\section{METODOLOGI}

Pada penelitian ini, metode yang digunakan adalah pendekatan kuantitatif dengan jenis penelitian terapan (applied research). Pendekatan kuantitatif digunakan untuk menganalisis kondisi aksesibilitas dan kualitas layanan prasarana transportasi dari dan menuju desa wisata berdasarkan persepsi publik melalui pengukuran dan perhitungan. Dan oleh karena itu, unit responden dalam penelitian ini yakni masyarakat (publik) yang pernah dan berpotensi mengunjungi desa wisata.

Penelitian ini menggunakan data primer dengan jenis data kuantitatif. Data tersebut diperoleh melalui angket/kuesioner untuk memperoleh persepsi publik mengenai kondisi aksesibilitas dan kualitas layanan prasarana transportasi dari dan menuju desa wisata, dengan mengacu pada parameter skala likert

Dalam penelitian ini digunakan teknik analisis data statistik deskriptif untuk menganalisis data dengan cara mendeskripsikan data yang telah terkumpul sebagaimana adanya tanpa bermaksud membuat kesimpulan yang berlaku untuk umum atau generalisasi. Data yang telah dikumpulkan dalam penelitian ini disajikan dalam bentuk table agar lebih mudah dibaca. Adapun jenis analisis deskriptif yang digunakan dalam penelitian ini yakni mean atau rata-rata. Mean digunakan untuk mencari nilai rata-rata dari total skor jawaban yang diberikan oleh responden. 


\section{HASIL DAN PEMBAHASAN}

Berdasarkan hasil penyebaran kuesioner, maka diperoleh hasil kondisi aksesibilitas dan kualitas layanan prasarana transportasi dari dan menuju desa wisata. Berikut ini hasil dan pembahasan tersebut.

\section{A. Road and Transport Insfrastrucuture and Community Support For Tourism}

Dampak lingkungan, manfaat, dan kepuasan masyarakat merupakan beberapa dampak yang dapat timbul dari pengembangan jalan dan infrastruktur transportasi serta pendukung masyarakat untuk pariwisata, sebagaimana disampaikan oleh Kanwal et al., (2020) dalam model konseptualnya. Untuk mengetahui kondisi aksesibilitas dan kualitas layanan prasarana transportasi dari dan menuju desa wisata, digunakan dampak lingkungan, manfaat, dan kepuasan masyarakat sebagai indikator pengukuran.

\section{1) Dampak Lingkungan}

Jawaban responden terhadap indikator dampak lingkungan dapat dilihat pada tabel 1 berikut.

Tabel 1. Hasil Kuesioner Indikator Dampak Lingkungan

\begin{tabular}{|l|c|c|c|c|c|c|}
\hline \multirow{3}{*}{ Butir Pertanyaan } & \multicolumn{7}{|c|}{ Dampak Lingkungan } & \multirow{2}{*}{ Rata-Rata } \\
\cline { 2 - 7 } & STS & TS & N & S & SS & \\
\cline { 2 - 7 } & $\mathbf{1}$ & $\mathbf{2}$ & $\mathbf{3}$ & $\mathbf{4}$ & $\mathbf{5}$ & \\
\hline Dampak Lingkungan 1 & 0 & 5 & 14 & 33 & 8 & 3,73 \\
\hline Dampak Lingkungan 2 & 0 & 6 & 19 & 32 & 3 & 3,53 \\
\hline Dampak Lingkungan 3 & 0 & 4 & 7 & 40 & 9 & 3,90 \\
\hline Dampak Lingkungan 4 & 1 & 3 & 13 & 38 & 5 & 3,72 \\
\hline Dampak Lingkungan 5 & 0 & 8 & 21 & 31 & 0 & 3,38 \\
\hline \multicolumn{9}{|c|}{ Total } \\
\hline \multicolumn{3}{|c|}{ Rata-Rata } \\
\hline
\end{tabular}

Sumber: Olah data penulis, 2021

Berdasarkan hasil penyebaran kuesioner, diperoleh rata-rata skor untuk pertanyaan 1 sebesar 3,73, yang menunjukkan bahwa responden setuju dengan pertanyaan tersebut. Sehingga, dapat disimpulkan bahwa menurut persepsi publik, pembangunan infrastruktur jalan dari dan menuju desa wisata akan menimbulkan kebisingan di daerah sekitarnya.

Selanjutnya, diperoleh rata-rata skor untuk pertanyaan 2 sebesar 3,53, yang menunjukkan bahwa responden setuju dengan pertanyaan tersebut. Sehingga, dapat disimpulkan bahwa menurut persepsi publik, pembangunan infrastruktur jalan dari dan menuju desa wisata akan menyebabkan peningkatan sampah di daerah sekitarnya. 
Kemudian, diperoleh rata-rata skor untuk pertanyaan 3 sebesar 3,90, yang menunjukkan bahwa responden setuju dengan pertanyaan tersebut. Sehingga, dapat disimpulkan bahwa menurut persepsi public, pembangunan infrastruktur jalan dari dan menuju desa wisata akan menimbulkan polusi suara di daerah sekitarnya.

Berikutnya, diperoleh rata-rata skor untuk pertanyaan 4 sebesar 3,72, yang menunjukkan bahwa responden setuju dengan pertanyaan tersebut. Sehingga, dapat disimpulkan bahwa menurut persepsi publik, pembangunan infrastruktur jalan dari dan menuju desa wisata akan merusak kualitas udara di daerah sekitarnya.

Kemudian, diperoleh rata-rata skor untuk pertanyaan 5 sebesar 3,38, yang menunjukkan bahwa responden setuju dengan pertanyaan tersebut. Sehingga, dapat disimpulkan bahwa menurut persepsi publik, pembangunan infrastruktur jalan dari dan menuju desa wisata akan mempenaruhi kualitas air di daerah sekitarnya.

Adapun dari 5 pertanyaan tersebut, diperoleh rata-rata skor sebesar 3,65, yang menunjukkan bahwa menurut persepsi publik, pembangunan infrastruktur jalan dari dan menuju desa wisata akan berdampak negatif terhadap lingkungan.

\section{2) Dampak Manfaat}

Jawaban responden terhadap indikator dampak manfaat dapat dilihat pada tabel 2 berikut.

Tabel 2. Hasil Kuesioner Indikator Dampak Manfaat

\begin{tabular}{|l|c|c|c|c|c|c|}
\hline \multirow{3}{*}{ Butir Pertanyaan } & \multicolumn{7}{|c|}{ Dampak Manfaat } & \multirow{2}{*}{ Rata-Rata } \\
\cline { 2 - 7 } & STS & TS & N & S & SS & \\
\cline { 2 - 7 } & $\mathbf{1}$ & $\mathbf{2}$ & $\mathbf{3}$ & $\mathbf{4}$ & $\mathbf{5}$ & \\
\hline Dampak Manfaat 1 & 0 & 0 & 4 & 10 & 46 & 4,70 \\
\hline Dampak Manfaat 2 & 0 & 0 & 5 & 6 & 49 & 4,73 \\
\hline Dampak Manfaat 3 & 0 & 0 & 3 & 7 & 50 & 4,78 \\
\hline \multicolumn{6}{|c|}{ Total } \\
\hline
\end{tabular}

Sumber: Olah data penulis, 2021

Berdasarkan hasil penyebaran kuesioner, diperoleh rata-rata skor untuk pertanyaan 1 sebesar 4,70, yang menunjukkan bahwa responden sangat setuju dengan pertanyaan tersebut. Sehingga, dapat disimpulkan bahwa menurut persepsi publik, pembangunan infrastruktur jalan dari dan menuju desa wisata akan meningkatkan kegiatan bisnis di daerah sekitarnya. 
Selanjutnya, diperoleh rata-rata skor untuk pertanyaan 2 sebesar 4,73, yang menunjukkan bahwa responden sanagt setuju dengan pertanyaan tersebut. Sehingga, dapat disimpulkan bahwa menurut persepsi publik, pembangunan infrastruktur jalan dari dan menuju desa wisata akan menghasilkan pengembangan bisnis baru di daerah sekitarnya.

Kemudian, diperoleh rata-rata skor untuk pertanyaan 3 sebesar 4,78, yang menunjukkan bahwa responden sangat setuju dengan pertanyaan tersebut. Sehingga, dapat disimpulkan bahwa menurut persepsi publik, pembangunan infrastruktur jalan dari dan menuju desa wisata akan mendukung perkembangan pariwisata di daerah sekitarnya.

Adapun dari 3 pertanyaan tersebut, diperoleh rata-rata skor sebesar 4,74, yang menunjukkan bahwa menurut persepsi publik, pembangunan infrastruktur jalan dari dan menuju desa wisata akan sangat berdampak dalam memberikan manfaat.

\section{3) Dampak Kepuasan Masyarakat}

Jawaban responden terhadap indikator dampak manfaat dapat dilihat pada tabel 3 berikut.

Tabel 3. Hasil Kuesioner Indikator Dampak Kepuasan Masyarakat

\begin{tabular}{|c|c|c|c|c|c|c|}
\hline \multirow{3}{*}{ Butir Pertanyaan } & \multicolumn{5}{|c|}{ Dampak Kepuasan Masyarakat } & \multirow{3}{*}{ Rata-Rata } \\
\hline & STS & TS & $\mathbf{N}$ & $\mathbf{S}$ & SS & \\
\hline & 1 & 2 & 3 & 4 & 5 & \\
\hline Dampak Kepuasan Masyarakat 1 & 0 & 1 & 7 & 30 & 22 & 4,22 \\
\hline
\end{tabular}

Sumber: Olah data penulis, 2021

Berdasarkan hasil penyebaran kuesioner, diperoleh rata-rata skor untuk pertanyaan 1 sebesar 4,22, yang menunjukkan bahwa responden sangat setuju dengan pertanyaan tersebut. Sehingga, dapat disimpulkan bahwa menurut persepsi publik, pembangunan infrastruktur jalan dari dan menuju desa wisata akan sangat meningkatkan standar hidup penduduk lokal secara signifikan.

\section{B. Kriteria Desa Wisata}

Menurut Arida \& Pujani, (2017) desa wisata merupakan wisata perdesaan yang menawarkan suasana kehidupan desa, nilai budaya, tradisi, dan lingkungan alam masyarakat setempat. Terdapat beberapa kriteria yang dijadikan tolak ukur sebuah desa untuk ditetapkan sebagai desa wisata, yakni aspek alam, lingkungan fisik, budaya, amenitas, SDM, kelembagaan, sikap dan tata kehidupan masyarakat, dan aksesibilitas (Ariadi \& Pujani, 
2017). Berkenaan dengan tujuan penelitan, kriteria yang digunakan sebagai indikator dalam penelitian ini difokuskan pada aspek lingkungan fisik, amenitas, dan aksesibilitas.

1) Lingkungan Fisik

Jawaban responden terhadap indikator lingkungan fisik dapat dilihat pada tabel 4 berikut.

Tabel 4. Hasil Kuesioner Indikator Lingkungan Fisik

\begin{tabular}{|c|c|c|c|c|c|c|}
\hline \multirow{3}{*}{ Butir Pertanyaan } & \multicolumn{5}{|c|}{ Lingkungan Fisik } & \multirow{3}{*}{ Rata-Rata } \\
\hline & STS & TS & $\mathbf{N}$ & $\mathbf{S}$ & SS & \\
\hline & 1 & 2 & 3 & 4 & 5 & \\
\hline Lingkungan Fisik 1 & 0 & 3 & 7 & 44 & 6 & 3,88 \\
\hline Lingkungan Fisik 2 & 0 & 2 & 8 & 43 & 7 & 3,92 \\
\hline & otal & & & & & 7,80 \\
\hline & a-Rata & & & & & 3,90 \\
\hline
\end{tabular}

Sumber: Olah data penulis, 2021

Berdasarkan hasil penyebaran kuesioner, diperoleh rata-rata skor untuk pertanyaan 1 sebesar 3,88, yang menunjukkan bahwa responden setuju dengan pertanyaan tersebut. Sehingga, dapat disimpulkan bahwa menurut persepsi publik, lingkungan fisik di sekitar kawasan suatu Desa Wisata relatif masih alami.

Selanjutnya, diperoleh rata-rata skor untuk pertanyaan 2 sebesar 3,92, yang menunjukkan bahwa responden setuju dengan pertanyaan tersebut. Sehingga, dapat disimpulkan bahwa menurut persepsi publik, terdapat persawahan atau perkebunan yang masih dominan di sekitar kawasan suatu Desa Wisata.

Adapun dari 2 pertanyaan tersebut, diperoleh rata-rata skor sebesar 3,90, yang menunjukkan bahwa menurut persepsi publik, Kawasan suatu Desa Wisata perlu memenuhi kriteria lingkungan fisik.

2) Amenitas

Jawaban responden terhadap indikator amenitas dapat dilihat pada tabel 5 berikut.

Tabel 5. Hasil Kuesioner Indikator Amenitas

\begin{tabular}{|l|c|c|c|c|c|c|}
\hline \multirow{3}{*}{ Butir Pertanyaan } & \multicolumn{7}{|c|}{ Amenitas } & \multirow{3}{*}{ Rata-Rata } \\
\cline { 2 - 7 } & STS & TS & $\mathbf{N}$ & $\mathbf{S}$ & SS & \\
\cline { 2 - 7 } & $\mathbf{1}$ & $\mathbf{2}$ & $\mathbf{3}$ & $\mathbf{4}$ & $\mathbf{5}$ & \\
\hline Amenitas 1 & 0 & 1 & 5 & 11 & 43 & 4,60 \\
\hline Amenitas 2 & 0 & 0 & 4 & 9 & 47 & 4,72 \\
\hline \multicolumn{6}{|c|}{ Total } \\
\hline
\end{tabular}

Sumber: Olah data penulis, 2021 
Berdasarkan hasil penyebaran kuesioner, diperoleh rata-rata skor untuk pertanyaan 1 sebesar 4,60, yang menunjukkan bahwa responden sangat setuju dengan pertanyaan tersebut. Sehingga, dapat disimpulkan bahwa menurut persepsi publik, pada suatu Desa Wisata perlu terdapat lahan parkir yang cukup luas yakni minimal dapat menampung 5 mobil.

Selanjutnya, diperoleh rata-rata skor untuk pertanyaan 2 sebesar 4,72, yang menunjukkan bahwa responden sangat setuju dengan pertanyaan tersebut. Sehingga, dapat disimpulkan bahwa menurut persepsi publik, pada suatu Desa Wisata perlu terdapat jalan yang aman dan memadai.

Adapun dari 2 pertanyaan tersebut, diperoleh rata-rata skor sebesar 4,66, yang menunjukkan bahwa menurut persepsi publik, Kawasan suatu Desa Wisata sangat perlu memenuhi kriteria amenitas.

3) Aksesibilitas

Jawaban responden terhadap indikator aksesibilitas dapat dilihat pada tabel 6 berikut.

Tabel 6. Hasil Kuesioner Indikator Aksesibilitas

\begin{tabular}{|l|c|c|c|c|c|c|}
\hline \multirow{3}{*}{ Butir Pertanyaan } & \multicolumn{7}{|c|}{ Aksesibilitas } & \multirow{2}{*}{ Rata-Rata } \\
\cline { 2 - 7 } & STS & TS & N & S & SS & \\
\cline { 2 - 7 } & $\mathbf{1}$ & $\mathbf{2}$ & $\mathbf{3}$ & $\mathbf{4}$ & $\mathbf{5}$ & \\
\hline Aksesibilitas 1 & 0 & 0 & 0 & 16 & 44 & 4,73 \\
\hline Aksesibilitas 2 & 1 & 5 & 9 & 35 & 10 & 3,80 \\
\hline Aksesibilitas 3 & 0 & 1 & 4 & 8 & 47 & 4,68 \\
\hline Aksesibilitas 4 & 0 & 1 & 14 & 34 & 11 & 3,92 \\
\hline \multicolumn{7}{|c|}{ Total } \\
\hline
\end{tabular}

Sumber: Olah data penulis, 2021

Berdasarkan hasil penyebaran kuesioner, diperoleh rata-rata skor untuk pertanyaan 1 sebesar 4,73, yang menunjukkan bahwa responden sangat setuju dengan pertanyaan tersebut. Sehingga, dapat disimpulkan bahwa menurut persepsi publik, pada suatu Desa Wisata sangat perlu terdapat jalan penghubung dari ke wilayah luar.

Selanjutnya, diperoleh rata-rata skor untuk pertanyaan 2 sebesar 3,80, yang menunjukkan bahwa responden setuju dengan pertanyaan tersebut. Sehingga, dapat disimpulkan bahwa menurut persepsi publik, suatu Desa Wisata perlu berjarak cukup dekat dengan pusat kota atau kabupaten.

Kemudian, diperoleh rata-rata skor untuk pertanyaan 3 sebesar 4,68, yang menunjukkan bahwa responden sangat setuju dengan pertanyaan tersebut. Sehingga, dapat 
disimpulkan bahwa menurut persepsi publik, pada suatu Desa Wisata sangat perlu memiliki moda transportasi lokal.

Berikutnya, diperoleh rata-rata skor untuk pertanyaan 4 sebesar 3,92, yang menunjukkan bahwa responden setuju dengan pertanyaan tersebut. Sehingga, dapat disimpulkan bahwa menurut persepsi publik, kepemilikan mobil pribadi di sekitar kawasan suatu Desa Wisata relatif rendah.

Adapun dari 4 pertanyaan tersebut, diperoleh rata-rata skor sebesar 4,28, yang menunjukkan bahwa menurut persepsi publik, pada suatu Desa Wisata sangat perlu memenuhi kriteria aksesibilitas.

\section{KESIMPULAN DAN SARAN}

Berdasarkan hasil dan pembahasan yang telah dipaparkan di atas, maka dapat ditarik kesimpulan sebagai berikut:

1. Menurut persepsi publik, pembangunan infrastruktur jalan dari dan menuju desa wisata akan; berdampak negatif terhadap lingkungan, sangat berdampak dalam memberikan manfaat, dan sangat meningkatkan standar hidup penduduk lokal secara signifikan.

2. Menurut persepsi publik, suatu desa wisata; perlu memenuhi kriteria lingkungan fisik, sangat perlu memenuhi kriteria amenitas dan aksesibilitas.

Berdasarkan hasil analisis minat masyarakat perkotaan terhadap layanan transportasi desa wisata, berikut saran yang diajukan:

1. Berdasarkan dampak negatif lingkungan dapat diatasi dengan melibatkan masyarakat sekitar desa wisata dalam proses pembangunan infrastruktur jalan. Selain itu pada penyusunan detail engineering design (DED) harus mempertimbangkan kajian lingkungan.

2. Pada penelitian ini hanya mengkaji desa wisata di Kota Bandung, agar dapatkan hasil yang menyeluruh sebaiknya diperluas menjadi desa wisata di Indonesia karena masingmasing desa wisata memiliki karakteristik yang berbeda. 


\section{DAFTAR PUSTAKA}

Adisasmita, S. A. (2012). Perencanaan Infrastruktur Transportasi Wilayah. Yogyakarta: Graha Ilmu.

Virkar, A. R., \& Mallya, P. D. (2018). A review of dimensions of tourism transport affecting tourist satisfaction. Indian Journal of Commerce \& Management Studies, 9(1), 72-80.

Arida, I. N. S., \& Sukma, N. (2017). Kajian Penyusunan Kriteria-Kriteria Desa Wisata Sebagai Instrumen Dasar Pengembangan Desawisata. Jurnal Analisis Pariwisata Issn, 1410-3729.

Dewi, M. H. U. (2013). Pengembangan desa wisata berbasis partisipasi masyarakat lokal di Desa Wisata Jatiluwih Tabanan, Bali. Jurnal Kawistara, 3(2).

Hermawan, H. (2016). Dampak pengembangan Desa Wisata Nglanggeran terhadap ekonomi masyarakat lokal. Jurnal Pariwisata, 3(2), 105-117.

Kanwal, S., Rasheed, M. I., Pitafi, A. H., Pitafi, A., \& Ren, M. (2020). Road and transport infrastructure development and community support for tourism: The role of perceived benefits, and community satisfaction. Tourism Management, 77, 104014.

Pearce, D. (1995). Tourism a Community Approach 2nd Edition. Harlow Longman.

Priasukmana, S., \& Mulyadin, R. M. (2001). Pembangunan desa wisata: Pelaksanaan undang-undang otonomi daerah. Info Sosial Ekonomi, 2(1), 37-44.

Soebiyantoro, U. (2010). Pengaruh ketersediaan sarana prasarana, sarana transportasi

terhadap kepuasan wisatawan. Jurnal Manajemen Pemasaran, 4(1), pp-16.

Sugima, A. G. (2013). Manajemen Aset Pariwisata: Pelayanan Berkualitas agar Wisatawan puas dan Loyal. Bandung: Guardaya intimarta.

Susanto, I. (2016). Perencanaan Pembangunan Pariwisata di Daerah (Studi Pelaksanaan Program pada Dinas Pemuda Olahraga dan Pariwisata Kabupaten Pekalongan). Jurnal Ilmiah Administrasi Publik, 2(3), 1-9.

Tamin, O. Z., Saleh, S. M., \& Bandung, F. I. (2008). Efisiensi Pemeliharaan Jalan Akibat Muatan Berlebih dengan Sistem Transportasi Barang Multimoda/Intermoda.

Virkar, A. R., \& Mallya, P. D. (2018). A review of dimensions of tourism transport affecting tourist satisfaction. Indian Journal of Commerce \& Management Studies, 9(1), 72-80.

Wulandari, Heny., Rina Indriani., Rima Untari., Samuel Bethagustav S. (2020). Statistik Kunjungan Wisatawan Mancanegara 2020. Jakarta: Badan Pusat Statistik Indonesia. 
Zakaria, F., \& Suprihardjo, R. (2014). Konsep Pengembangan Kawasan Desa Wisata di Desa Bandungan Kecamatan Pakong Kabupaten Pamekasan. Jurnal teknik ITS, 3(2), C245C249. 